\title{
Development of antifungal paper from Trametes versicolor containing orange oil against fungal skin infections: A model based on in vitro studies
}

\author{
Sirimas Sukmas ${ }^{1}$, Tanong Aewsiri ${ }^{1,2}$ and Narumol Matan ${ }^{1,2 *}$ \\ ${ }^{1}$ Food Science and Technology, School of Agricultural Technology, Walailak University, Nakhon Si Thammarat 80160, Thailand \\ ${ }^{2}$ Research Center of Excellence in Innovation of Essential oil, Walailak University, Nakhon Si Thammarat 80160, Thailand
}

\begin{abstract}
Introduction: Mould infection on the human skin is one of important effects of mould on human health. Skin mould infection is normally caused by Aspegillus, Penicillium and Rhizopus. To date, orange oil has been applied in the present study to inhibit mould infection by adding it into fungal paper. Fungal paper made from Trametes versicolor was used to absorb and slow down the release of orange oil vapour. Therefore, the objective of this work was to investigate the effect of orange oil in fungal paper on growth of infected skin mould as a model in vitro test.
\end{abstract}

Methods: Orange oil and the main component (limonene) was prepared in the Malt Extract Agar (MEA) and added into fungal paper made from T. versicolor at concentrations of 0 (control), 20, 40, 60, 80 and $100 \mu \mathrm{g} \mathrm{g}^{-1}$. Each of mycelium and spores of Aspergillus niger, Aspergillus flavus, Penicillium chrysogenum and Rhizopus spp were placed on the MEA. A spore of mould was sprayed on the fungal paper.

Results: Using $60 \mu \mathrm{g} \mathrm{g} \mathrm{g}^{-1}$ of orange oil in MEA and $80 \mu \mathrm{g} \mathrm{g} \mathrm{g}^{-1}$ of orange oil in the fungal paper exhibited complete inhibition of growth of all moulds in this test. Limonene alone could not inhibit all moulds in this test; therefore, some minor components of orange can play a significant role in mould growth inhibition. Moreover, fungal paper made from $T$. versicolor exhibited slow release of orange oil components with active to inhibit mould at least 30 days.

Conclusions: Thus, this research demonstrated the potential of fungal paper containing orange oil to control the growth of infected moulds and that this combination could be applied in medicine to control infection of skin in the future.

\section{Practical application}

Fungal paper made from $T$. versicolor containing orange oil has the potential to be used to control fungal skin infection in the long-term. This technique is beneficial for avoiding resistant from the chemical treatment when orange oil vapours are safe for using. This process requires attentiveness and is simple to apply for large-scale antifungal paper processing.

\section{Introduction}

Aspergillus, Penicillium and Rhizopus are common fungal skin infections in human. A. flavus, A. niger and A. fumigatus are widely known to cause superficial infection in immunuocompromised individuals [1]. However, Rhizopus mould infection has been increasingly reported for soft-tissue infections in the immunocompetent [2]. In addition, Penicillium chrysogenum has been found to cause an invasive infection in immunocompromised hosts [3]. Nowadays, many kinds of drugs are recognised for controlling those of moulds. However, the epidemiology of mould infections needs to find better and easy application to deliver drugs in the skin.

Essential oils (Eos) are natural preservatives $[4,5]$ that can be extracted from parts of natural plants such as root, flower, bud and leaves. For centuries, EOs have been widely used for food preservation and flavour to apply with food products that have antimicrobial activity, which have effects on bacterial and fungal cells. One such essential oil is orange oil, a natural active compound derived from the orange plant, whose antifungal activity depends on its active compounds such as limonene, linalool and citral. The main active compound of orange oil is limonene; limonene's antimicrobial activity has been widely investigated, and this compound can inhibit growth of fungal cells, including the spore germination elongation and the mycelium development process as a component of paper dressing [6-8]. ViudaMartos et al. found that orange oil can inhibit mycelium growth of Aspergillus species [9]. The application of orange oil to food products is growing in popularity, and it is highly effective against several types of bacteria and fungi [10-13]. However, the application of EOs in paper dressing can be releasing and directly to the wound skin and rapidly dispersed have not been confirmed.

Trametes versicolor is a common white-rot fungus of wood that can produce extracellular enzymes that degrade agricultural waste and exopolysaccharides in many cultures of media [14]. T. versicolor could be used to make a fungi pulp and have been used to produce paper box

*Correspondence to: Narumol Matan, Food Science and Technology, School of Agricultural Technology, Walailak University, Nakhon Si Thammarat 80160, Thailand and Research Center of Excellence in Innovation of Essential oil, Walailak University, Nakhon Si Thammarat 80160, Thailand, Tel: 6675672359; Fax:6675672971; E-mail: nnarumol@wu.ac.th; nnarumol@yahoo.com

Key words: orange oil, fungal skin infection, fungal paper

Received: March 20, 2019; Accepted: June 03, 2019; Published: June 06, 2019 
packaging [13]. Fungi mycelium pulp looks like paper pulp. It has a low cost for producing paper or bio-composite packaging and can be combined a plant or cellulose fibres of plants to improve some properties $[15,16]$. Some researchers use a combination of fungi mycelium with cellulose of plant for holding the plant substrate pieces together, without the use of synthetic adhesives [13]. Fungi mycelium can be applied as a biodegradable alternative for a wide range for application with other materials in industrial processes, food and medicine. Fungal paper is friendly to the environment and is easy to biodegrade. However, the use of fungal paper to adsorb and release EOs is still limited; therefore, was the objective of this research.

\section{Materials and methods}

\section{Orange oil and limonene}

Orange oil and limonene were obtained from Thai China Flavors \& Fragrances Co., Ltd of Bangkok, Thailand.

\section{Fungal strains}

For fungal paper production, Trametes versicolor (WU 0704) was isolated from a bamboo tree. The code refers to the strains held in the culture collection of the Center of Excellence in Wood Science and Engineering, Walailak University, Nakhon Si Thammarat province, Thailand. Fungi were grown on a malt extract agar (MEA; Merck Ltd, Thailand) medium at $30^{\circ} \mathrm{C}$ for 7 days.

For antifungal testing, the fungal strains of Aspergillus niger, Aspergillus flavus, Rhizopus spp. and Penicillium chrysogenum were obtained from the microbiology laboratory of Walailak University, Nakhon Si Thammarat province of Thailand. Mycelium grown on MEA (Merck Ltd., Thailand) was prepared for 7 days at $25^{\circ} \mathrm{C}$ before testing.

\section{Minimum inhibition concentration and minimum fungicidal concentrations of orange oil and limonene}

The study evaluated the effect of orange oil and the main component of orange oil (limonene) at concentrations of 0 (control) to $100 \mu \mathrm{g} \mathrm{g}^{-1}$ MEA on growth of infection moulds (A. niger, A. flavus, Rhizopus spp. and $P$. chrysogenum) were done using the agar dilution method. After agar preparation, $0.1 \mathrm{~mL}$ of suspension of each mould strain was added on the surface of the agar. In addition, mycelium of the mould $(\varphi 5 \mathrm{~mm})$ was placed on an MEA plate and then incubated at $25^{\circ} \mathrm{C}$ for 3 days. The lowest concentration of orange oil and limonene that showed no growth of spore and mycelium on MEA was reported as the MIC. After 3 days of incubation, MEA containing the spore $(\varphi 5 \mathrm{~mm})$ of mould that exhibited no growth on the agar and the mycelium of the mould from the MIC test was then placed on MEA and incubated at $25^{\circ} \mathrm{C}$ for 3 days again. MFC was reported from the MEA plate with no growth of spore and mycelium.

\section{Preparation of antifungal paper from Trametes versicolor containing orange oil}

A paper $(5 \mathrm{~cm}$ long and $2 \mathrm{~cm}$ wide) was produced from $10 \mathrm{~g}$ of fungal pulp (T. versicolor). The fungal pulp was sterilised at $121^{\circ} \mathrm{C}$ for 15 minutes and mixed with the orange oil at concentrations of 20 to 100 $\mu \mathrm{g} \mathrm{g}^{-1}$. Next, the fungal pulp was placed into the box and dried in a tray at $60^{\circ} \mathrm{C}$ for 5 hours.

\section{Inhibitory effect of fungal paper containing orange oil on the mould infection test}

Aqueous spore suspensions of $1 \mathrm{ml}$ of each mould (A. niger, A. flavus, Rhizopus spp. and P. chrysogenum) were sprayed on the surface of fungal paper containing orange oil. Then, the paper was placed in a Petri dish and incubated at $25^{\circ} \mathrm{C}$ and $100 \% \mathrm{RH}$ until mould grew on the surface. The papers containing mould were then individually rated for mould growth on a scale of 0 to 5 , with 0 denoting clean specimens and 5 representing heavy mould growth $(0=$ clean, $1=20 \%, 2=40 \%, 3=60 \%$, $4=80 \%$ and $5=100 \%$ of mould growth). The percentage inhibition of mould growth was next computed by the following equation:

Percentage inhibition of mould growth (based on the control $)=($ AB/A) $\times 100 \ldots$ (Eq. 1)

where $\mathrm{A}=$ total score for each mould at control,

$\mathrm{B}=$ total score for each mould at each concentration of the essential oil.

\section{Results}

\section{MICs and MFCs of orange oil and limonene}

The effect of orange oil on the growth of infection moulds is illustrated in Table 1. Using concentrations of orange oil of $20 \mu \mathrm{g} \mathrm{g}^{-1}$ (MIC) and $60 \mu \mathrm{g} \mathrm{g}^{-1}$ (MFC) to inhibit spores and mycelia of all moulds exhibited significant inhibition of all infection moulds in this test. By contrast, higher MIC and MFC of limonene were found to be $60 \mu \mathrm{g}$ $\mathrm{g}^{-1}$ and $>100 \mu \mathrm{g} \mathrm{g}^{-1}$, respectively, for inhibition of spores of all moulds, although $20 \mu \mathrm{g} \mathrm{g}^{-1}$ and $>100 \mu \mathrm{g} \mathrm{g}^{-1}$ of MIC and MFC were demonstrated to be highly effective on mycelium growth of all moulds.

\section{Antifungal activity of fungal paper from Trametes versicolor containing orange oil}

The concentration of orange oil $\left(80 \mu \mathrm{g} \mathrm{g}^{-1}\right)$ that inhibits growth of A. niger, A. flavus, Rhizopus spp. and P. chrysogenum on fungal paper was found at a storage day of 30 days. All results on the effect of fungal paper containing orange oil on each mould in this test over 30 days had the same results. Therefore, only the antifungal activity of the fungal paper containing orange oil against $A$. niger for 30 days is illustrated in Figures 1 and 2. Figure 1 exhibits that the inhibition ability of orange oil in fungal paper at a concentration of $60 \mu \mathrm{g} \mathrm{g}^{-1}$ as MFC had the lowest inhibition of $A$. niger ( $70 \%)$ in 30 days of storage. Therefore, higher concentration of orange oil $\left(80 \mu \mathrm{g} \mathrm{g}^{-1}\right)$ in the fungal paper was required for the paper to inhibit growth of all moulds.

\section{Discussion}

From Table 1, complete growth inhibitions of all moulds occurred at $60 \mu \mathrm{g} \mathrm{g}^{-1}$. Although Velázquez-Nuñez et al. [17] explained that the minimum inhibitory concentration for the growth of A. flavus by direct addition of orange peel oil was $16,000 \mathrm{mg} \mathrm{l}^{-1}$ and 8,000

Table 1. MICs and MFCs of orange oil and limonene against mould infection on MEA

\begin{tabular}{|c|c|c|c|c|}
\hline \multirow{3}{*}{ Mold } & \multicolumn{4}{|c|}{ Spore germination } \\
\hline & \multicolumn{2}{|c|}{ Orange oil $\left(\mu \mathrm{g} \mathrm{g}^{-1}\right)$} & \multicolumn{2}{|c|}{ Limonene $\left(\mu \mathrm{g} \mathrm{g}^{-1}\right)$} \\
\hline & MIC & MFC & MIC & MFC \\
\hline Aspergillus flavus & 5 & 60 & 60 & $>100$ \\
\hline Aspergillus niger & 5 & 40 & 60 & $>100$ \\
\hline Penicillium chrysogenum & 5 & 40 & 60 & $>100$ \\
\hline \multirow[t]{2}{*}{ Rhizopus spp. } & 20 & 60 & 5 & $>100$ \\
\hline & \multicolumn{4}{|c|}{ Mycelium } \\
\hline Aspergillus flavus & 5 & 60 & 20 & $>100$ \\
\hline Aspergillus niger & 5 & 40 & 20 & $>100$ \\
\hline Penicillium chrysogenum & 5 & 40 & 20 & $>100$ \\
\hline Rhizopus spp. & 20 & 60 & 5 & $>100$ \\
\hline
\end{tabular}




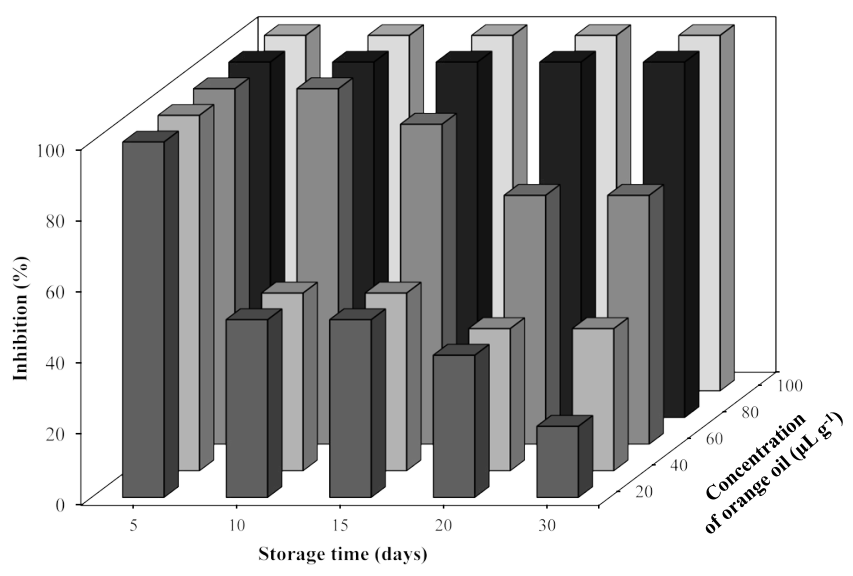

Figure 1. Inhibition (\%) of orange oil against $A$. niger on the surface of fungal paper

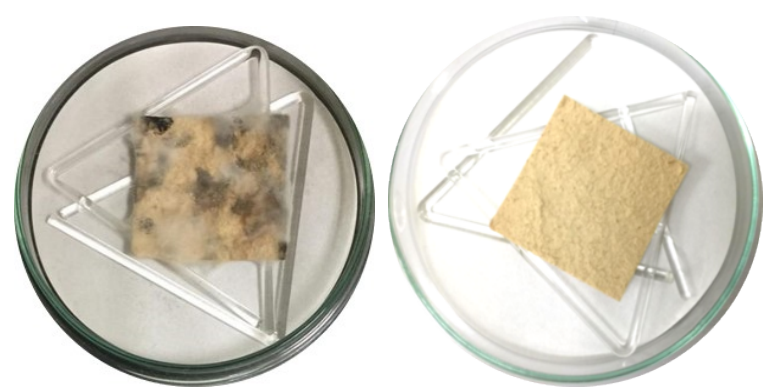

Figure 2. Fungal paper containing A. niger without orange oil (A) and with orange oil (B) at 30 days of storage

$\mathrm{mg}$ of $\mathrm{EO} \mathrm{l}^{-1}$ of air for vapour contact, it was found that orange peel oil direct addition was faster. However, orange peel EO vapours were more effective, since lower concentrations were required to achieve the same antifungal effect. When orange oil was adsorbed into the agar, some component of orange oil vapour could be vaporised through the surface of the agar; then, the spore could not germinate, and mycelium of the mould was suppressed. In the present study, it was observed that orange oil had higher antimicrobial potential against Aspergillus and Penicillium than against Rhizopus. By contrast, regarding the effect of limonene on growth of mould in this test, results in Table 1 confirmed that limonene was a stronger inhibitor to mycelia of all moulds than to spores, especially to mycelium of Rhizopus. Although limonene not only failed to completely inhibit all moulds with the MFC $>100 \mu \mathrm{g} \mathrm{g}^{-1}$, it was more active against Rhizopus than orange oil. The differences were due to the other main components of the orange oil which accumulated over the agar medium.

The growth inhibition due to the limonene alone was found to be incomplete against mycelia and spores of all moulds. The synergic effect of other components of orange oil was more active against infected moulds than that of limonene alone. Regarding the different compositions of $\alpha$-pinene (2.79\% of orange oil), was shown often resistance on bacteria, yeast and fungi. Moreover, $\alpha$-pinene can have diverse synergistic effects with other compounds of essential oil that exhibited strong inhibition of Aspergillus growth [18]. Furthermore, Edinardo et al. suggested that Sabinene (3.55\% of orange oil) was found to be a potential component to have a synergistic effect with other compounds that reduced the MIC of antibiotics tested against bacteria [19].
To slow the release of orange oil vapours from fungal paper, the pore size of the fungal paper and the concentration of orange oil were both required to design. The inhibition ability of the fungal paper containing orange oil against mould growth on infected human skin depended on the controlled release of orange oil vapours. Normally, fungal paper containing the hydroxyl group made from T. versicolor contain a large polysaccharide group called chitin. Chitin consists of a linear biopolymer $(\beta-(1,4)$-linked $\mathrm{D}-\mathrm{N}$-acetylglucosamine $(\mathrm{GlcN})$ and $\mathrm{N}$-glucosamine (GlcNAc)) units in various proportions and sequences [20] that make starch very hydrophilic and sensitive to moisture or relative humidity $[21,22]$ From this result, it can be seen that fungal paper could slow down the release of orange oil that proved highly effective against mould for at least 30 days. The mechanism of controlling the release could be explained as follows. After the fungal paper containing orange oil absorbed moisture from the environment, the hydrophilicity was increased; this can be able barrier to component in essential oil (hydrophobic). Then, the release of the active orange is found with antifungal activity (Figure 3 ) $[23,24]$. Therefore, these fungal papers containing orange oil are highly likely to be used to improve the release of essential oil for medical purposes.

Nevertheless, bio-based packaging produced from fungi mycelia can also be incorporated with EOs to inhibit microbial on paper surfaces and extend to shelf-life of food products packed inside biobased packaging [13]. Normally, cell walls of fungi have the ability to produce chitin. Chitin is a linear homopolymer of $\mathrm{N}$-acetylglucosamine linked by $\beta-1,4$ glycosidic bonds [25]. Around more than 20 chitin chains could be composed by intramolecular and intermolecular hydrogen bonds to perform of microfibrils that have high tensile strength for producing packaging [26]. The incorporation of EOs in fungi-based food packaging is an approach to correcting the associated with biopolymer-based and have been reported by Srikaew et al. [13].

Nevertheless, after EOs have been released the active compound to cells of microorganisms, components of EOs can be released into the cell walls of microorganisms. As a result of passing these components to the cell, the cell membrane, the cytoplasm, enzymes and proteins of bacteria are interrupted, and they can completely change the conformation of the microbial cell. Furthermore, a microorganism's loss of ions or metabolites due to exposure to EOs can compromise the microbial metabolism and be damage and undergo cell death [27,28]. A case study of Srikaew et al. [13] demonstrated paper from fungi mycelium containing clove oil can inhibit mould growth of $A$. flavus. Songsamoe et al. [29] and Suhem et al. [30] also reported that components of essential oil could delay spore germination of moulds and inhibition of the mycelium of mould.

\section{Conclusions}

The orange oil $\left(80 \mu \mathrm{g} \mathrm{g}^{-1}\right)$ adsorbed by fungal paper can release active compounds to inhibit fungal growth of isolated mould.

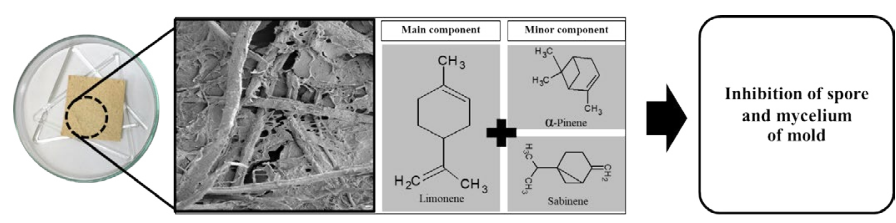

Figure 3. Scanning electron microscope image at $500 \times$ of fungal paper containing orange oil 
Furthermore, fungal paper that has adsorbed orange oil can develop as a dressing paper that prevents fungi and bacteria infection and that is safe for human use; thus, it is a potential candidate to apply the orange oil adsorbed into paper dressing to for damage infected wounds.

Fungal skin infection (A. niger, A. flavus, Rhizopus spp. and $P$. chrysogenum) can be controlled by the application of fungal paper containing orange oil; such a paper could also be used as a replacement for the conventional fungicide chemical treatment. Orange oil in antifungal paper has shown the antifungal activities of biocontrol agents on fungi skin infection for a long time. Mould infection may occur on the human skin before it deeply grows, but this takes time. The present demonstrated one of the major modes of action of antifungal paper used for 30 days; the fungal paper released higher levels of D-limonene and could work together with other components in controlling the growth of moulds during long-term use.

\section{Acknowledgements}

This study was supported by the Walailak University fund (Grant no. WU60611 and WU 03/2560).

\section{References}

1. Struck M, Gille J (2013) Fungal infections in burns: A comprehensive review. Ann Burns Fire Disasters 26: 147-153.

2. Becker WK, Cioffi WG, McManus AT, Kim SH, McManus WF, et al. (1991) Fungal burn wound infection: A 10-year experience. Arch Surg 126: 44-48.

3. Tribble DR, Rodriguez CJ (2014) Combat-related invasive fungal wound infections. Curr Fungal Infect Rep 8: 277-286.

4. Matan N, Puangjinda K, Phothisuwan S, Nisoa M (2015) Combined antibacterial activity of green tea extract with atmospheric radio-frequency plasma against pathogens on fresh-cut dragon fruit. Food control 50: 291-296.

5. Palou L, Ali A, Fallik E, Romanazzi G (2016) GRAS, plant-and animal-derived compounds as alternatives to conventional fungicides for the control of postharvest diseases of fresh horticultural produce. Postharvest Biol Technol 122: 41-52.

6. Deba F, Xuan TD, Yasuda M, Tawata S (2008) Chemical composition and antioxidant, antibacterial and antifungal activities of the essential oils from Bidens pilosa Linn. var. Radiata. Food control 19: 346-352.

7. Dambolena J, López A, Cánepa M, Theumer M, Zygadlo J, (2008) Inhibitory effect of cyclic terpenes (limonene, menthol, menthone and thymol) on Fusarium verticillioides MRC 826 growth and fumonisin B1 biosynthesis. Toxicon 51: 37-44.

8. Zhang J, Bing L, Reineccius GA (2015) Formation, optical property and stability of orange oil nanoemulsions stabilized by Quallija saponins. LWT Food Sci Technol 64: 1063-1070.

9. Viuda-Martos M, Ruiz-Navajas Y, Fernández-López J, Pérez-Álvarez J (2008) Antifungal activity of lemon (Citrus lemon L.), mandarin (Citrus reticulata L.), grapefruit (Citrus paradisi L.) and orange (Citrus sinensis L.) essential oils. Food control 19: 1130-1138.

10. Severino R, Ferrari G, Vu KD, Donsì F, Salmieri S, et al. (2015) Antimicrobial effects of modified chitosan based coating containing nanoemulsion of essential oils, modified atmosphere packaging and gamma irradiation against Escherichia coli $\mathrm{O} 157$ : $\mathrm{H} 7$ and Salmonella Typhimurium on green beans. Food control 50: 215-222.
11. Sánchez Aldana D, Contreras-Esquivel J, Nevárez-Moorillón G, Aguilar C (2015) Caracterización de películas comestibles a base de extractos pécticos y aceite esencial de limón Mexicano. CyTA J Food 13: 17-25.

12. Alparslan Y, Yapıсı HH, Metin C, Baygar T, Günlü A, et al. (2016) Quality assessment of shrimps preserved with orange leaf essential oil incorporated gelatin. LWT Food Sci Technol 72: 457-466.

13. Srikaew B, Matan N, Aewsiri T (2017) Innovative production of fungal pulp from Trametes versicolor and its application in a fungal paper box containing clove oil. $J$ Food Sci Technol 54: 3058-3064.

14. Schlosser D, Grey R, Fritsche W (1997) Patterns of ligninolytic enzymes in Trametes versicolor. Distribution of extra-and intracellular enzyme activities during cultivation on glucose, wheat straw and beech wood. Appl Microbiol Biotechnol 47: 412-418.

15. Holt LJ, Turner N, Mokbel N, Trefely S, Kanzleiter T, et al. (2012) Grb10 regulates the development of fiber number in skeletal muscle. FASEB J 26: 3658-3669.

16. Abhijith R, Ashok A, Rejeesh CR (2018) Sustainable packaging applications from mycelium to substitute polystyrene: A review. Mater Today 5: 2139-2145.

17. Velázquez-Nuñez MJ, Avila-Sosa R, Palou E, López-Malo A (2013) Antifungal activity of orange (Citrus sinensis var. Valencia) peel essential oil applied by direct addition or vapor contact. Food control 31: 1-4.

18. Ložienė K, Švedienè J, Paškevičius A, Raudonienė V, Sytar O, et al. (2018) Influence of plant origin natural $\alpha$-pinene with different enantiomeric composition on bacteria, yeasts and fungi. Fitoterapia 127: 20-24.

19. Matias EF, Alves EF, Silva MK, Carvalho VR, Figueredo FG, et al. (2016) Seasonal variation, chemical composition and biological activity of the essential oil of Cordia verbenacea DC (Boraginaceae) and the sabinene. Ind Crops Prod 87: 45-53.

20. Hassainia A, Satha H, Boufi S (2018) Chitin from Agaricus bisporus: Extraction and characterization. Int J Biol Macromol 117: 1334-1342.

21. Basiak E, Lenart A, Debeaufort F (2017) Effect of starch type on the physico-chemical properties of edible films. Int J Biol Macromol 98: 348-356.

22. Henrique CM, Teófilo RF, Sabino L, Ferreira MMC, Cereda MP (2007) Classification of cassava starch films by physicochemical properties and water vapor permeability quantification by FTIR and PLS. J Food Sci 72: 184-189.

23. Ghayempour S, Montazer M (2019) A novel controlled release system based on Tragacanth nanofibers loaded Peppermint oil. Carbohydr Polym 205: 589-595.

24. Chaemsanit S, Sukmas S, Matan N, Matan N (2019) Controlled release of peppermint oil from paraffin-coated activated carbon contained in sachets to inhibit mold growth during long term storage of brown rice. J Food Sci 84: 832-841.

25. Merzendorfer H (2011) The cellular basis of chitin synthesis in fungi and insects: Common principles and differences. Eur J Cell Biol 90: 759-769.

26. Rudall KM, Kenchington W (1973) The chitin system. Biol Rev 48: 597-633.

27. Burt SA, Reinders RD (2003) Antibacterial activity of selected plant essential oils against Escherichia coli O157: H7. Lett Appl Microbiol 36: 162-167.

28. Burt S (2004) Essential oils: Their antibacterial properties and potential applications in foods-a review. Int J Food Microbiol 94: 223-253.

29. Songsamoe S, Matan N, Matan N (2017) Antifungal activity of Michelia alba oil in the vapor phase and the synergistic effect of major essential oil components against Aspergillus flavus on brown rice. Food control 77: 150-157.

30. Suhem K, Matan N, Matan N, Danworaphong S, Aewsiri T (2017) Enhanced antifungal activity of michelia oil on the surface of bamboo paper packaging boxes using heliumneon $(\mathrm{HeNe})$ laser and its application to brown rice snack bar. Food control 73: 939945

Copyright: (C2019 Sukmas S. This is an open-access article distributed under the terms of the Creative Commons Attribution License, which permits unrestricted use, distribution, and reproduction in any medium, provided the original author and source are credited. 